\title{
A novel minimally invasive percutaneous facet augmentation device for the treatment of lumbar radiculopathy and axial back pain: technical description, surgical technique and case presentations
}

Um novo dispositivo percutâneo minimamente invasivo de aumento facetário para o tratamento da radiculopatia lombar e dor axial lombar: descrição técnica, técnica cirúrgica e apresentação de casos

Un nuevo dispositivo percutáneo mínimamente invasivo de aumento facetáreo para el tratamiento de radiculopatía lumbar y dolor axial lumbar: descripción técnica, técnica quirúrgica y presentación de casos

\author{
Larry T. Khoo* \\ Nan Fu Chen* \\ Sean Armin* \\ Eric Stiner \\ Juan Dipp* \\ Ricardo Flores* \\ Sylvain Palmer*
}

\section{ABSTRACT}

Objective: to describe a new posterior minimally invasive method of facet stabilization for treatment of the degenerating lumbar motion segment. The biomechanics of this Percudyn (Interventional Spine; Irvine, CA) system are distinct from that of other interspinous dynamic stabilization systems as it acts bilaterally directly within the middle column of the spine. Based on biomechanical evalution, the paired prosthesis supports, cushions, and reinforces the facet complexes by limiting both extension and lateral bending thereby maintaining central and foraminal volumes. Methods: the Percudyn device consists of a pedicle anchor upon which sits a cushioning polycarbonate-urethane stabilizer that serves as a mechanically reinforcing
\end{abstract}

\section{RESUMO}

Objetivo: descrever um método de estabilização facetária posterior minimamente invasivo para tratamento de segmento móvel degenerativo. A biomecânica do sistema Percudyn (Interventional Spine, Irvine, Califórnia) é distinta de outros sistemas de estabilização dinâmica inter-espinhosa, pois este atua direta e bilateralmente dentro da coluna média da coluna vertebral. Baseada em avaliações biomecânicas, a prótese dupla dá suporte, atua como amortecedor e reforça os complexos facetários limitando a extensão ea inclinação lateral, mantendo assim os volumes centrais e foraminais. Métodos: o sistema Percudyn consiste de uma ancora pedicular sobre a qual está apoiado um estabilizador de plicarbonatouretano que atua como um bloqueio

\section{RESUMEN}

Objetivo: describir un método de estabilización facetárea posterior mínimamente invasiva para tratamiento del segmento móvil degenerativo. La biomecánica del sitema Percudyn (Interventional Spine, Irvine, California) es distinta de otros sistemas de estabilización dinámica interespinosa, pues ésta actúa directamente y bilateralmente dentro de la columna media de la columna vertebral. Con base en evaluaciones biomecánicas, la prótesis dupla da soporte, actúa como amortiguador y refuerza los complejos facetáreos limitando la extensión y la inclinación lateral, manteniendo así los volúmenes centrales y foraminales. Métodos: el sistema Percudyn consiste de un áncora pedicular sobre la cual está apoyado un estabilizador de policarbonato-uretano, que actúa como un bloqueo mecánica-

Study carried out of University of California Los Angeles Comprehensive Spine Center - Santa Monica (CA), USA.

"Assistant Professor of Neurological \& Orthopedic Surgery of the University of California Los Angeles Comprehensive Spine Center - Santa Monica (CA), USA. 
stop between the inferior and superior articular facets. A $1.5 \mathrm{~cm}$ skin incision is made bilaterally over the lower pedicle of the treated segment through which a Jamshidi needle is percutaneously targeted under biplanar fluoroscopic guidance into the caudal aspect of the superior articular process directly underneath the lip of the inferior facet from the level above. Progressive onestep tubular dilation is then performed to secure a small disposable working portal. Through this access, the Percudyn stabilizers are then placed over the wire and anchored bilaterally into the inferior pedicles of the degenerated motion segment. Results: three patients (ages 26-41, male) with significant low back pain as well as radiculopathy with lateral recess stenosis from a large disc herniation/ ligamentum and facet hypertrophy (L4-5 and/or L5-S1) underwent a minimally invasive decompression/ discectomy and bilateral Percudyn placement at each disease level. Each patient had significant relief of both his radiculopathy and axial back pain post-operatively and was discharged home within 18 hours without sequelae. Conclusion: this novel technique of percutaneous posterior facet augmentation allows for safe placement of bilateral middle column prostheses that act as mechanical cushions between the articulating facets thereby limiting extension and lateral bending and also preventing compression of the neural elements. As the Percudyn device serves to reinforce the middle colu$\mathrm{mn}$ directly at the level of the facet, it represents a new class of posterior motionpreserving stabilization which may serve to mitigate segmental axial back pain as has been described for other posterior dynamic stabilization systems.

KEYWORDS: Radiculopathy; Orthopedics procedures/methods; Surgical procedures, minimally invasive/instrumentation; Low back pain/surgery; Spinal fusion/ instrumentation/methods mecanicamente reforçado entre as facetas inferiores e superiores. Uma incisão na pele de $1,5 \mathrm{~cm}$ é feita bilateralmente sobre o pedículo inferior do segmento a ser tratado, por meio da qual é introduzida percutaneamente uma agulha de Jamshidi com auxílio de fluoroscopia biplanar em direção da porção caudal do processo articular superior, diretamente abaixo da borda da faceta inferior do nível superior. É feita uma dilatação tubular progressiva para assegurar um pequeno e temporário portal de trabalho. Por meio desse acesso, os estabilizadores Percudyn são colocados sobre o fio e ancorados bilateralmente nos pedículos inferiores de cada segmento móvel degenerativo. Resultados: três pacientes (idade de 26 a 41 anos, sexo masculino) com lombalgia significativa, assim como radiculopatia e estenose do recesso lateral em consequência de um grande fragmento de disco herniado, ou hipertrofia ligamentar e facetária (L4-5 e/ou L5-S1) foram submetidos a uma descompressão/discectomia minimamente invasiva e implantação do Percudyn bilateralmente em cada segmento afetado. Todos os pacientes tiveram um alivio pós-operatório significante, tanto da radiculopatia como da dor axial lombar, e alta hospitalar até 18 horas sem sequelas da intervenção. Conclusão: esta nova técnica percutânea de aumento posterior das facetas permite a colocação segura de próteses da coluna média que agem como um amortecedor mecânico entre as facetas articulares, limitando assim a extensão e a inclinação lateral, prevenindo também a compressão dos elementos neurais. $\mathrm{Na}$ medida em que os dispositivos Percudyn servem para reforçar a coluna média diretamente no nível da faceta, representam uma nova classe de estabilizadores com preservação do movimento que atuam para reduzir a dor axial lombar, como já descrito com outros sistemas de estabilização mecânica.

DESCRITORES: Radiculopatia; Procedimentos ortopédicos/ métodos; Procedimentos cirúrgicos minimamente invasivos/ instrumentação; Dor lombar/cirurgia mente reforzado entre las facetas inferiores y superiores. Una incisión en la piel de $1.5 \mathrm{~cm}$ es hecha bilateralmente sobre el pedículo inferior del segmento a ser tratado, a través del cual es introducida percutáneamente una aguja de Jamshidi con auxilio de fluoroscopia biplanar en dirección a la porción caudal del proceso articular superior, directamente abajo del borde de la faceta inferior del nivel superior. Es hecha una dilatación tubular progresiva para sujetar un pequeño y temporal portal de trabajo. A través de este acceso, los estabilizadores Percudyn son puestos sobre el hilo o alambre y ancorados bilateralmente en los pediculos inferiores de cada segmento móvil degenerativo. Resultados: tres pacientes (edad de 26 a 41 años, sexo masculino) con lumbalgia significativa, así como radiculopatía y estenosis del receso lateral en consecuencia de un fragmento grande del disco herniado, o hipertrofia ligamentar y facetárea (L4-5 y/o L5-S1) fueron sometidos a una descompresión/ disectomía mínimamente invasiva e implantación del Percudyn bilateralmente en cada segmento afectado. Todos los pacientes tuvieron un alivio postoperatorio significativo tanto de la radiculopatía así como del dolor axial lumbar y tuvieron alta hospitalar hasta 18 horas sin secuelas de la intervención. Conclusión: esta nueva técnica percutánea de aumento posterior de las facetas permite la colocación segura de prótesis de la columna media que actúan como un amortiguador mecánico entre las facetas articulares, limitando asi la extensión y la inclinación lateral, previniendo también la compresión de los elementos neurales. En la medida en que los dispositivos Percudyn sirven para reforzar la columna media directamente en el nivel de la faceta, pueden representar una nueva clase de estabilizadores con preservación del movimiento que actúan para reducir el dolor axial lumbar, como ya descrito con otros sistemas de estabilización mecánica.

DESCRIPTORES: Radiculopatía; Procedimientos ortopédicos/ métodos; Procedimientos quirúrgicos mínimamente invasivos/instrumentación; Dolor de la región lumbar/cirugía 


\section{INTRODUCTION}

The degenerating lumbar spine is a major source of low back pain and disability in western industrial societies. Both the degenerating disc and spondylolitic facet joints are thought to be potential pain generators in symptomatic patients with dysfunctional lumbar motion segments. Recently introduced dynamic stabilization devices have been designed to alleviate pain by purportedly stiffening or supporting the motion segment in attempt to restore the native biomechanical neutral zone. Examples of these devices include the Dynesys (Zimmer Spine), DIAM (Medtronics; Minneapolis, MN), X-STOP (Kyphon Inc) and the Wallis Devices (Abbott Spine; Austin, TX). These "dynamic stabilizers" have typically required open exposures with concomitant stripping of the very musculature and ligaments that maintain the intrinsic stability of the spine. We describe a new type of posterior facet augmentation device (Percudyn; Interventional Spine Inc; Irvine, CA) that serves to stabilize the middle column of the spine through a novel bilateral mechanism. The prostheses are delivered percutaneously into the bilateral superior articular processes (SAP) of the inferior vertebral body (VB) where they serve as a mechanical stop to the inferior articulating process (IAP) coming down from the level above thereby directly augmenting the stiffness of the facet column. From a biomechanical perspective, the Percudyn serves primarily to limit extension and lateral bending of the treated lumbar level, therefore also preventing further compression of the spinal canal, neural foramen, and posterior disc. As compared to the majority of other interspinous devices, the Percudyn is unique in that two key aspects: 1) It is truly minimally invasive as can be placed completely percutaneously without the need for any muscle or ligament stripping, and 2) It acts to stabilize the middle column bilaterally as it acts in both facets thereby having effect in lateral bending as well. In this technical note, we describe the surgical procedure for implantation of the paired Percudy prosthesis for treatment of degenerative lumbar disc disease.

\section{Operative Technique}

Once the induction of general or local anesthesia has been achieved, the patient is positioned prone on a Jackson or other compatible radiolucent operative table. Every effort should be made to maintain a reasonable lordosis at the treated level and to avoid kyphogenic frames or positioning. Under fluoroscopic guidance, the pedicles of the inferior body of the treated level are visualized and appropriate small $1 \mathrm{~cm}$ incisions marked. The incision site is localized and marked with fluoroscopy from the posterior side with the image exactly on top of pedicle where the device will be implanted. After local anesthetic containing 25\% Marcaine with 1:200,000 epinephrine is injected preoperatively along these tissue pathways, the area is then prepped and draped in the usual sterile fashion. An approximately $15 \mathrm{~mm}$ incision is made with a \#11 blade through skin and fascia. An access needle is then introduced through this incision through the musculature under fluoroscopy towards the fluoroscopic pedicle target. The tip of the needle is walked along the facet and docked ensuring that it is exactly positioned at the bottom of the IAP approximately in the middle of the oval fluoroscopic pedicle shape (Figure 1A, 1B). After verification of the needle docking position, the targeting needle is inclined 10 degrees medially and 10 degrees caudally to obtain a trajectory that will lie within the pedicle but also maintain a near orthogonal orientation to the face of the SAP and the plane of the facet joint itself (Figure 1C). The access needle is then advanced through the pedicle into the posterior aspect of the vertebral body under biplanar fluoroscopic guidance. The central core of the access needle is then exchanged via Seldinger technique for a Kirschner-wire which is then advanced slightly further into the vertebral body (Figure 1D). A proprietary one step "Teleport" sequential dilator is then introduced down to the pedicle entry point along the K-wire. The novel mechanism of this introducer allows for efficient serial dilation without the need for multiple tube exchanges to rapidly establish the small working corridor to each pedicle (Figure 2A). A $3.0 \mathrm{~mm}$ cannulated drill is then used to coaxially drill down the $\mathrm{K}$-wire stopping just short of the tip in order to avoid plugging the drill tip with bone (Figure 2B). The drill is then retracted, and the pathway prepared with a $4 \mathrm{~mm}$ tap (Figure 2C). A favorable countersink at the level of the SAP and facet joint is then created with a $10 \mathrm{~mm}$ cannulated ball-shaped rasp to establish a seat for the

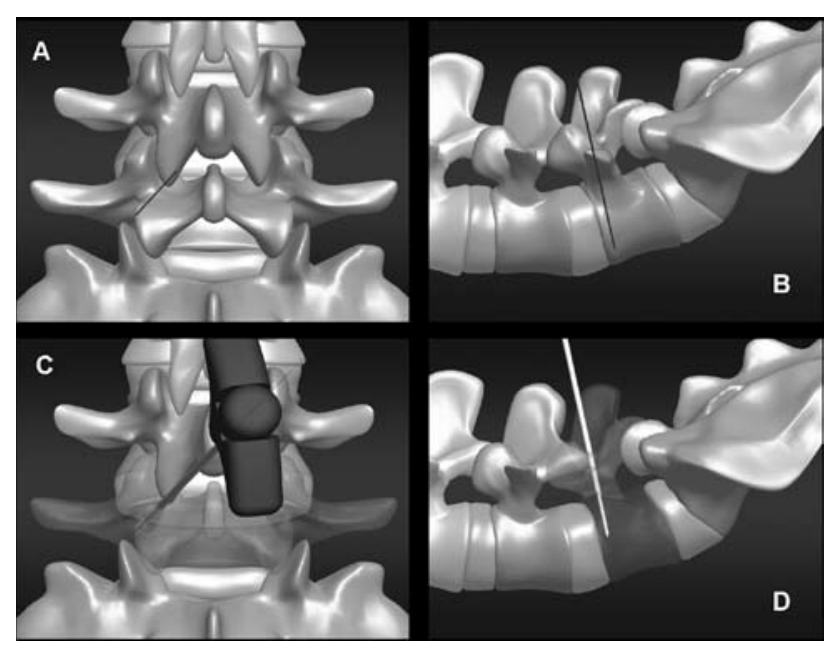

Figure 1

Sequential operative procedure for placement of access needle and K-wire: A) Trajectory of the Jamshidi access needle on anterior-posterior view; B) Trajectory of the Jamshidi access needle on lateral view; C) The access needle is advanced through pedicle; D) The central core of the needle is exchanged for a Kirschner wire 


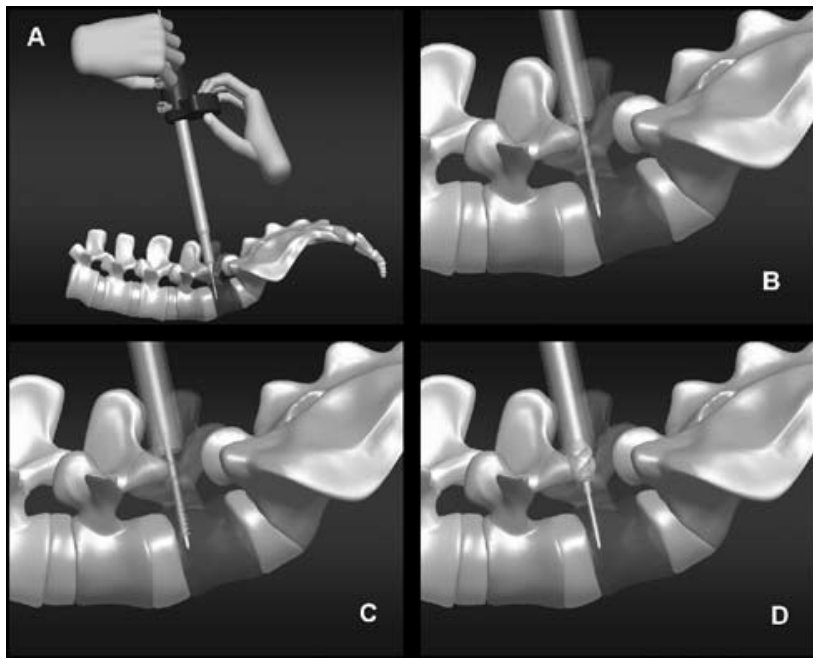

Figure 2

Soft tissue dilatation, drill, tapping, and countersink shaving of the bone: A) Soft tissue dilatation is achieved by introducing the Teleport dilator; B) The anchor path is drilled over the K-wire; C) The anchor threads are tapped over the K-wire; D) The countersink shaver is used to prepare the PCU head seat between the facets

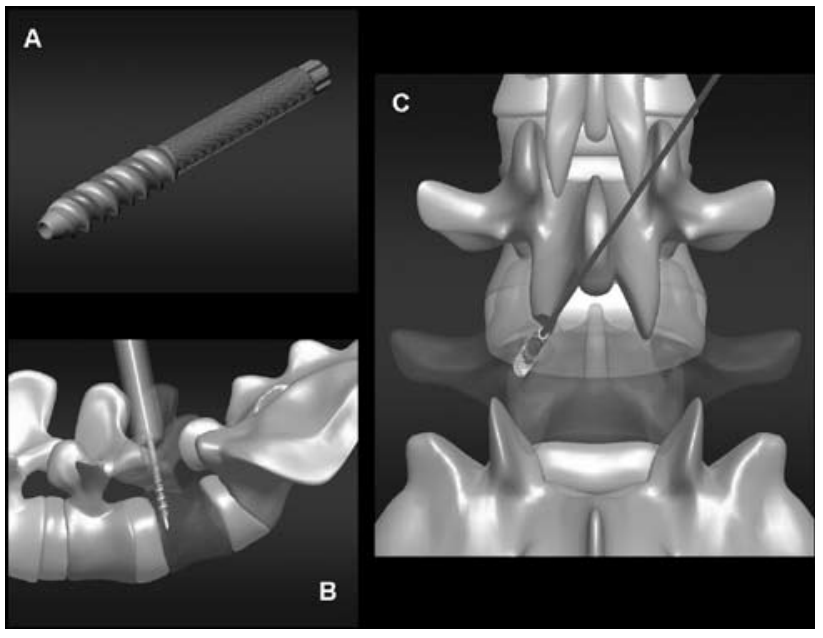

Figure 3

Placement of the anchor screw over the K-wire into the pedicle: A) Schematic of the anchor screw; B, C) The anchor is seen in final position in an AP and lateral view

\section{Illustrative cases}

\section{Case 1}

This 41-year-old male presented with a 5 year history of central mechanical low back pain and lumbar radicular pain. The pain was greater on the left than on the right. His pain was exacerbated by a motor vehicle accident 15 months prior to admission. The pain was exacerbated by mechanical activities such as standing and walking and was relieved by sitting or lying down. He was found to have L4-5, L5-S1 degenerative disc disease with bilateral recess stenosis at L5-S1 (Figure 5A). He failed a 6-month polycarbonate (PCU) head of the Percudyn prosthesis bilaterally (Figure 2D). A hollow $4.5 \mathrm{~mm}$ diameter titanium screw of appropriate length to just purchase the dorsal vertebral body is then introduced under fluoroscopic guidance into each pedicle to serve as the anchor of each prosthesis (Figure 3A, 3B, 3C). The unique design of the screwdriver allows for disengagement of the anchor once it has been fully seated in the SAP to prevent over countersinking. The cannulated polycarbonate - urethane stabilizer (PCU) head is then introduced over the wire down to the prepared bony seat (Figure 4A, 4B, 4C). After fluoroscopic confirmation of the implant position, the PCU head is then impacted and locked to the $4.5 \mathrm{~mm}$ anchor. As the head is locked and compressed, the polycarbonate ring radially expands thereby further seating within and distracting the facet joint. The same series of steps is then repeated on the contralateral side (Figure 4D). After the intial, simultaneous placement of bilateral Percudyn devices can be readily achieved in very rapid fashion.

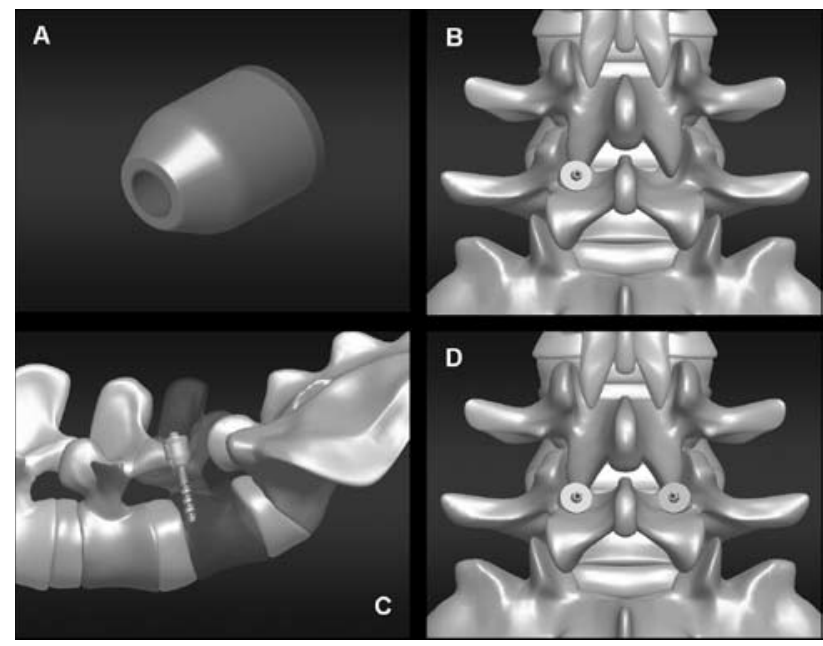

Figure 4

Insertion of PCU stabilizer: A) Picture of PCU stabilizer; $B, C$ ) $P C U$ stabilizer is installed onto the anchor, AP and lateral view; D) Final AP view after bilateral PercuDyn placement

course of conservative management that consisted of physical therapy as well as multiple injections including facet blocks that provided him only with short-term relief. His pain not well relieved by Vicodin and muscle relaxants. For that reason he elected to undergo bilateral L5-S1 minimally invasive lamionotomy, medial facetectomy, and foraminotomy for decompression of the neural elements and dynamic posterior stabilization of L4-5 and L5-S1 with the Percudyn prostheses (Figure 5B, 5C). The decompression required 45 minutes and the implantation an additional 
35 minutes with a total blood loss of $20 \mathrm{cc}$ and a hospital stay of 18 hours. He tolerated the procedure well and had excellent relief his radiculopathy as well as improvement of the mechanical central pain as well. (VAS leg: 88/100 preop, 10/100 6wks, 1/100 3mos, 0/100 6mos); VAS back: 67/100 preop, 45/100 6wks, 17/100 3mos, 10/100 6 mos; ODI: 38 preop, 21 at 6 mos). He has returned to work and full activity with only intermittent use of non-steroidal anti-inflammatory for pain (Figure 5).

\section{Case 2}

This 39-year-old male had a history of $60 \%$ right L5 radiculopathy and $40 \%$ low central back pain with no sensory or motor deficits. Imaging revealed L4-5 degenerative disc disease with a large right-sided disc herniation at L4-5 on MR imaging (Figure 6A, 6B). He had attempted conservative management for five months, which included physical therapy and injections without relief. His pain was mostly located in the lower lumbar area as a band with radiation to the right side buttock and leg in a L5 distribution. Where as sitting and bending to the left eased his radiculopathy, it also greatly exacerbated his central axial low back pain. He underwent a right-sided minimally invasive microsurgical laminotomy and microdiscectomy via a tubular approach for treatment of his radiculopathy. As he had a significant component of mechanical back pain, we discussed with him the various options including fusion, artificial disc placement, and dynamic posterior stabilization. Whereas he did not wish to have fusion, he also did not feel that he could tolerate his mechanical back pain at the present level. He thus ultimately chose to have bilateral L4-5 posterior percutaneous Percudyn dynamic stabilization in addition to his decompression (Figure 6C, 6D). The decompression and stabilization required 40 and 30 minutes respectively with minimal blood loss and a five hours stay in the hospital. His radiculopathy resolved early on postoperatively with a good response in his back pain as well. (VAS leg: 91/100 preop, 5/100 6wks, 0/100 - 4mos); (VAS back: 87/100 preop, 45/100 6wks, 30/100 4mos); (ODI: 35 preop, 21 at 4 mos).

\section{Case 3}

This 26-year-old male had low back pain for one year superimposed upon which he then developed new left sided $\mathrm{S} 1$ radicular pain and mild plantar flexion weakness with tension signs. The radicular pain was far more debilitating than his chronic low back pain causing him to be unable to work with difficulty ambulating. Both his leg and back pain were worsened by sitting and standing and relieved with lying down. Preoperatively, he required 2 to 4 vicodin tablets per day in conjunction with 2 tablets of Flexeril to manage his pain. He was found to have left sided L5-S1 vertical foraminal stenosis on MRI. In an effort to decompress his right S1 nerve as well as to alleviate his significant axial mechanical back pain, he elected to undergo a left L5-S1 minimally-invasive tubular microsurgical decompression and microdiscectomy with placement of bilateral L5-S1 PercuDyn stabilizers (Figure 7A, 7B). Total surgical time

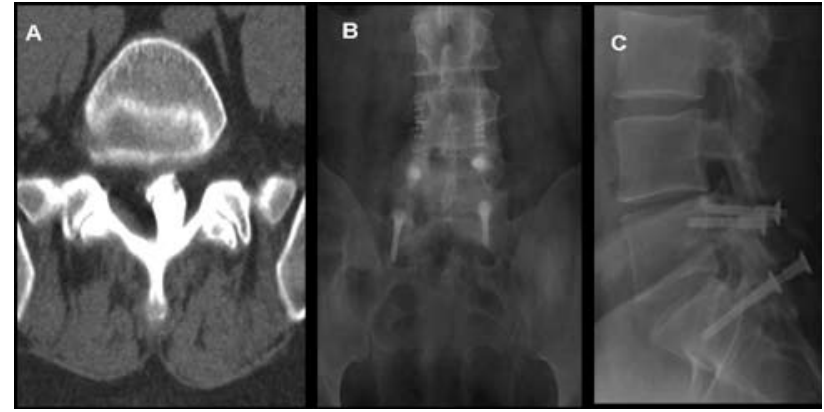

Figure 5

Case 1: 41 years old male patient with L4-5 degenerative disc disease as well as bilateral S1 stenosis from soft tissue hypertrophy. (A) Preoperative CT Mylogram; (B, C) PostopAP and lateral radiographs after PercuDyn implantation

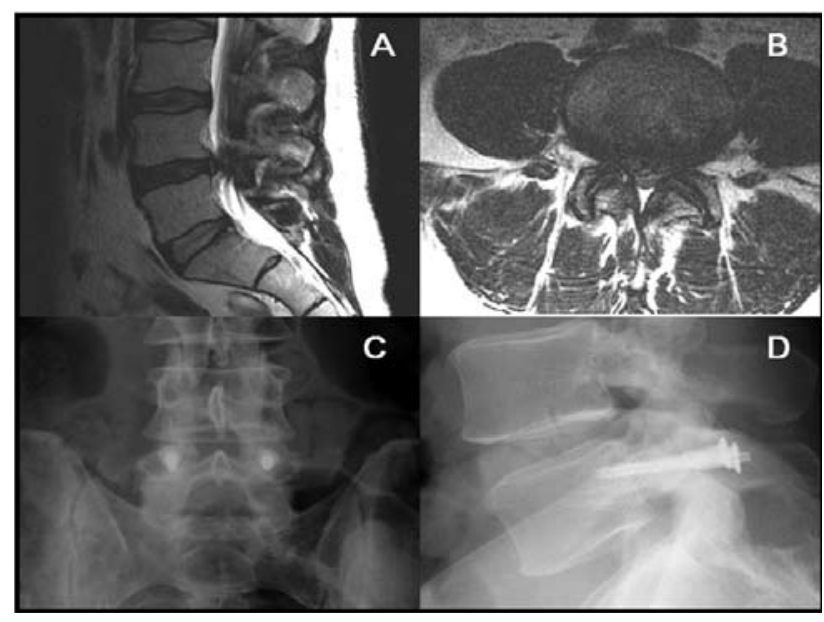

Figure 6

Case 2: 39 year old male patient with disc degeneration and right paracentral herniation at the L4-5 level. (A) Preoperative sagittal T2WI MR imaging reveals the disc herniation with compression of the neural elements; $(B)$ Preoperative axial T2WI MR imaging showing right-sided stenosis caused by herniated disc; (C,D) Postoperative AP and lateral radiographs after implantation of PercuDyn prostheses

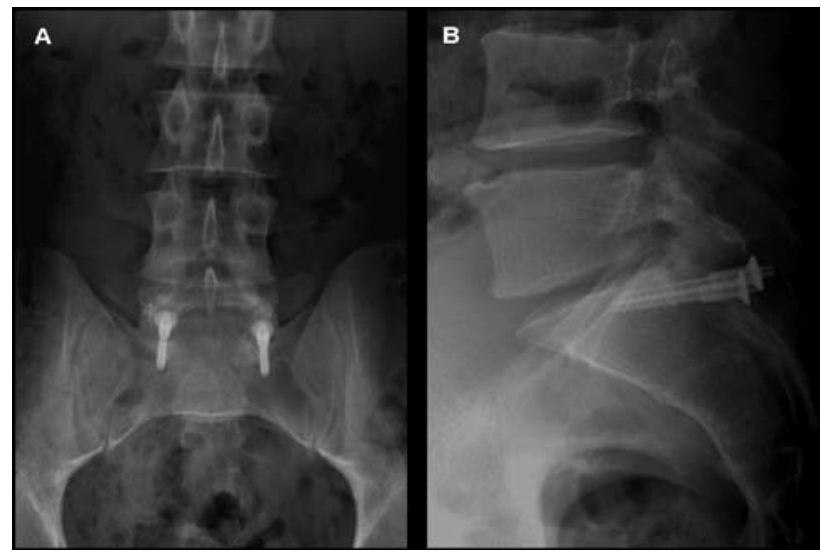

Figure 7

Case 3: 26 year old male patient with disc degeneration and herniation at L4-5 level. (A,B) Postoperative AP and lateral radiographs after implantation of PercuDyn 
was 1 hour and 10 minutes with minimal blood loss and no complications. Post-operatively, his radicular pain completely resolved and he was discharged 4 hours later. By his initial 10 day postoperative visit, he was able to discontinue all of his narcotic medications and took only a two ibuprofen $200 \mathrm{mg}$ tablets once to twice a day. (VAS leg: 90/100 preop, 0/100 6wks, 0/100 - 4mos); (VAS back: 80/100 preop, 30/100 6wks, 15/100 4mos); (ODI: 41 preop, 19 at 4 mos).

\section{DISCUSSION}

Traditionally, decompression, stabilization and the correction of existing deformity have been the hallmarks of surgical management of low back pain or lumbar instability. However, there has not been a corresponding improvement in clinical outcomes despite a high fusion rate has been achieved with the advances in biomedical technique and instruments ${ }^{1-2}$. Some people have chronic back pain but their imaging studies did not reveal evidences of instability or neurologic compression. Degenerative change of the spine has been considered an important source of low back pain $^{3}$. Spinal degeneration may include disc degeneration, facet joint osteoarthritis, vertebral body degeneration and ligament degeneration ${ }^{4}$. However, initial degenerative change of the spine usually begins with intervertebral disc degeneration especially from nucleus pulposus and the intervertebral disc is considered to be a predominant source of low back pain by many clinicians and researchers ${ }^{5,7}$. The magnitude, duration and frequency of load and pressure are all related to disc degeneration. Excessive load causes loss of disc height, degradation of extracellular matrix, increased apoptosis and disorganization of the cellular architecture ${ }^{8}$. Diminished blood supply to the intervertebral disc was considered to initiate tissue breakdown and this may start as early as in the second life decade $e^{7,9}$. In this degenerative process, dehydration of nucleus and weakness of annulus develop which causes loss of its resistance to rotation and translational forces ${ }^{8}$. With advancing degeneration, the proportion of load transmitted through the nucleus decreases but through the posterior elements increases ${ }^{10,12}$. This result was similar to Yang and King's study that facet load for segments with degenerated discs increases significantly ${ }^{13}$. Thus subsequent degeneration of the facet joints usually follows disc degeneration or develops concomitantly which may in turn cause low back pain ${ }^{12,14,15}$.

Within the confines of degenerative disc disease, there is a significant gap between the conservative and total disc replacement. The treatment options may vary from activity modification, nonsteroidal anti-inflammatory drugs, physiotherapy, epidural injection, IDET or fusion. Before emergence of "dynamic stabilization" concept, those who failed to response to conservative treatment could only choose rigid metallic lumbar fusion or motion-preserving arthroplasty. However, a considerable amount of morbidity and complications after fusion surgery have being reported gradually ${ }^{16,18}$. In addition, the elimination of mobility at the fused level may cause adjacent segments degeneration which usually requires re-interventions ${ }^{19-21}$. The artificial disc replacement is a good option to degenerative disc disease treatment. It can not only preserve the motion of operated segment but also reduce the mechanical forces transmitted to the adjacent segments ${ }^{22,23}$. Nevertheless, this set of devices requires good facets, posterior ligaments, and muscular structures that limited its application in those who have facet hypertrophy ${ }^{24}$. Unfortunately, the degeneration of discs and facet joints always develops simultaneously.

As a consequence, some investigators explored alternative approaches to stabilize the lumbar spine. One important concept is "dynamic stabilization" which adopts semirigid stabilization to restrict motion in the direction or plane that produced pain, or painful motion, but would otherwise allow a full range of motion and therefore maintain function ${ }^{25,26}$. It would ideally improve the movement and the load transfer of a spinal segment but without the intention of fusion. So far, a lot of posterior dynamic stabilization systems have been developed in the literature. These can be classified into three main categories. The first is a pedicle-based dynamic rod system such as Dynesys, Graf ligament, AccuFlex rod or Scient's $\mathrm{X}$ Isobar. The second is an interspinous process-based system such as the DIAM, X STOP, Coflex and Wallis. The third total facet replacement system such as TFAS, TOPS and Stabilimax NZ is emerging recently ${ }^{27-34}$. The goal of dynamic stabilization is to induce a regression of the degenerative process in the pathologic disc structure. Animal models with controlled dynamic disc distraction on degenerated intervertebral discs suggest that disc regeneration can be induced. The decompressed discs showed signs of tissue recovery on a biologic, cellular, and a biomechanical level ${ }^{35}$. Guehring reported signs of rehydration of the nucleus on MRI after distraction of rabbit intervertebral disc ${ }^{36}$. Lafage and Gangnet et al. showed in their in vitro study that the stress in disc fibers and annulus matrix could be reduced by implantation of Wallis interspinous device ${ }^{37}$. Similar results also have been reported after implantation of X-stop on cadaver human spines $^{38}$. The X-stop interspinous implant significantly reduced the mean peak pressure, average pressure, contact area, and force of facet joints at the implanted level during extension $^{39}$. Therefore, from above researches, we can reasonably predict that the disc pressure will be reduced by alleviating facet joint load. Then, it is likely to slow down disc degeneration and regression of the degenerative process in pathologic disc can also be expected.

Based on the above concept, an implant for posterior dynamic stabilization system called "Percudyn" was developed. The stabilizers of Percudyn devices are placed between the inferior articulating facets of the upper vertebral body and the superior articular facets of the inferior vertebral body to "off-load" the facet joints by acting like a "bumper" and dissipate energy forces dorsally. By alleviating the load of facet joints, the intadiscal pressure will be reduced concomitantly. It showed $84 \%$ less compression of the posterior disc during extension and 
$70 \%$ less compression during axial loading. The foraminal area of the instrumented spine was 36\% larger than in intact spines during extension and $9 \%$ larger during flexion ${ }^{40}$.

Although the biomechanism of Percudyn is similar to that of other interspinaous stabization systems, its surgical approach method is totally different. The Percudyn can be surgically inserted bilaterally only through two $15-\mathrm{mm}$ incisions. Instead of cutting muscle, the instrument can be inserted just dilating it with the aid of minimally invasive access ports. It is really a percutaneous procedure. Unlike other interspinaous stabilization systems, which require a $4-5 \mathrm{~cm}$ midline incision and muscle dissection to expose laminae and facet joints to ensure proper placement of implant. It can be performed percutaneously alone or combined with other decompression procedures depending on patients' diverse conditions. In addition, most of the interspinous process stabilization systems are not suitable for use at L5-S1 level because of short and small S1 spinal process. However, you can apply Percudyn at S1 level without this problem.

It is not easy to obtain a good surgical result by using one surgical approach to treat all degenerative spine disorders because the mechanisms and processes of DDD may be different in everyone. Nevertheless, it is important to determine which device is best suited for a certain patient at a given stage of the disease process. KirkaldyWillis and Farfan presented a concept of three phases of degeneration: dysfunction, unstable, and restabilization of the motion segment. The first phase is disc degeneration. The secondary phase is facet joint degeneration accompanied by ligamentous laxity and muscular insufficiency. In the third phase, stability is regained by disc collapse, osteochondrosis, spondylophytes, and locking of the facets $^{41}$. We attempt to use Percudyn to alter the late first phase and cover all mechanical aspects of the second phase of degenerative disc disease. Through abating facet joint load and reducing intradiscal pressure, we expect to slow down or even regression the disc degenerative process. Although, we have got a good response in our initial three cases, we still need multicenter prospective randomized clinical trials to evaluate its safety and effectiveness in the near future.

\section{CONCLUSION}

Because the theoretical background of DDD is incomplete, the actual designs of all these novel implants can not be perfect. No device is suitable for any phase of DDD. Although there are diversible methods for treatment of degenerative disc disease, we prefer to adopt a technically simpler surgery to treat this problem and can obtain a satisfactory result as well. The Percudyn is really a minimally invasive percutaneous device and its use does not restrict or eliminate any potential future therapeutic options. It is hoped that further studies will shed light on the advantages of this surgical technique on the treatment for symptomatic DDD.

\section{REFERÊNCIAS}

1. Boos N, Webb JK. Pedicle screw fixation in spinal disorders: a European view. Eur Spine J. 1997; 6(1):2-18.

2. Gibson JN, Grant IC, Waddell G. The Cochrane review of surgery for lumbar disc prolapse and degenerative lumbar spondylosis. Spine. 1999; 24(17):1820-32.

3. Vanharanta H, Sachs BL, Spivey MA, Guyer RD, Hochschuler SH, Rashbaum RF, et al. The relationship of pain provocation to lumbar disc deterioration as seen by CT/ discography. Spine. 1987; 12(3): 295-8.

4. Fujiwara A, Lim TH, An HS, Tanaka $\mathrm{N}$, Jeon CH, Andersson GB, et al. The effect of disc degeneration and facet joint osteoarthritis on the segmental flexibility of the lumbar spine. Spine. 2000; 25(23):3036-44.

5. Buckealter JA. Aging and degeneration of the human intervertebral disc. Spine. 1995; 20(11):1307-14.
6. Vernon-Roberts B. Age-related and degenerative pathology of intervertebral discs and apophyseal joints. In: Jayson MI, editor. The lumbar spine and back pain. Edinburgh: Churchill Livingstone; 1992. p.17-41.

7. Haefeli M, Kalberer F, Saegesser D, Nerlich AG, Boos N, Paesold G. The course of macroscopic degeneration in the human lumbar intervertebral disc. Spine. 2006;31(14):1522-31.

8. Schnake KJ, Putzier M, Haas NP, Kandziora F. Mechanical concepts for disc regeneration. Eur Spine J. 2006;15 Suppl 3:S354-60.

9. Boos N, Weissbach S, Rohrbach H, Weiler C, Spratt KF, Nerlich AG. Classification of age-related changes in lumbar intervertebral discs: 2002 Volvo Award in basic science. Spine. 2002;27(23):2631-44.

10.McNally DS, Adams MA. Internal disc mechanics as revealed by stress profilometry. Spine. 1992; 17(1):6673.
11. Shirazi-Adl A, Ahmed AM, Shrivastava SC. A finite element study of a lumbar motion segment subjected to pure sagittal plane moments. J Biomech. 1986; 19(4): 331-50.

12.Niosi CA, Oxland TR. Degenerative mechanics of the lumbar spine. Spine J. 2004; (6 Suppl): 202S-208S.

13. Yang KH, King AI. Mechanism of facet load transmission as a hypothesis for low-back pain. Spine. 1984; 9(6): 557-65.

14.Fujiwara A, Lim TH, An HS, Tanaka $\mathrm{N}$, Jeon $\mathrm{CH}$, Andersson GB, et al. The effect of disc degeneration and facet joint osteoarthritis on the segmental flexibility of the lumbar spine. Spine. 2000;25(23):3036-44.

15.Fujiwara A, Tamai K, An HS, Kurihashi T, Lim TH, Yoshida H, et al. The relationship between disc degeneration, facet joint osteoarthritis, and stability of the degenerative lumbar spine. J Spinal Disord. 2000;13(5):444-50. 
16.Rompe JD, Eysel P, Zöllner J, Nafe B, Heine J. Degenerative lumbar spinal stenosis. Long-term results after undercutting decompression compared with decompressive laminectomy alone or with instrumented fusion. Neurosurg Rev. 1999;22(2-3):102-6.

17.Fritzell $\mathrm{P}$, Hägg $\mathrm{O}$, Nordwall A; Swedish Lumbar Spine Study Group. Complications in lumbar fusion surgery for chronic low back pain: comparison of three surgical techniques used in a prospective randomized study. A report from the Swedish Lumbar Spine Study Group. Eur Spine J. 2003;12(2):178-89.

18.Christensen FB. Lumbar spinal fusion. Outcome in relation to surgical methods, choice of implant and postoperative rehabilitation. Acta Orthop Scand Suppl. 2004; 75(313):243.

19.Rahm MD, Hall BB. Adjacentsegment degeneration after lumbar fusion with instrumentation: a retrospective study. J Spinal Disord. 1996;9(5): 392-400.

20.Schlegel JD, Smith JA, Schleusener RL. Lumbar motion segment pathology adjacent to thoracolumbar lumbar and lumbosacral fusions. Spine. 1996; 21(8): 970-81.

21. Whitecloud TS 3rd, Davis JM, Olive PM. Operative treatment of the degenerated segment adjacent to a lumbar fusion. Spine. 1994;19(5):531-6.

22.Lemaire JP, Carrier H, Sariali el-H, Skalli W, Lavaste F. Clinical and radiological outcomes with the Charité artificial disc: a 10-year minimum follow-up. J Spinal Disord Tech. 2005;18(4):353-9.

23.McAfee PC, Cunningham B, Holsapple G, Adams K, Blumenthal $\mathrm{S}$, Guyer RD, et al. A prospective, randomized, multicenter Food and Drug Administration investigational device exemption study of lumbar total disc replacement with the CHARITE artificial disc versus lumbar fusion: part II: evaluation of radiographic outcomes and correlation of surgical technique accuracy with clinical outcomes. Spine. 2005;30(14):1576-83; discussion E388-90.

24.Geisler FH. Surgical technique of lumbar artificial disc replacement with the Charité artificial disc. Neurosurgery. 2005;56(1 Suppl):4657; discussion 46-57.
25.Sengupta DK. Dynamic stabilization devices in the treatment of low back pain. Orthop Clin North Am. 2004;35(1):43-56.

26. Schnake KJ, Putzier M, Haas NP, Kandziora F. Mechanical concepts for disc regeneration. Eur Spine J. 2006;15 Suppl 3:S354-60.

27. Schwarzenbach O, Berlemann U, Stoll TM, Dubois G. Posterior dynamic stabilization systems: DYNESYS. Orthop Clin North Am. 2005;36(3):363-72.

28.Taylor J, Pupin P, Delajoux S, Palmer S. Device for intervertebral assisted motion: technique and initial results. Neurosurg Focus. 2007; 22(1):E6.

29. Chiu JC. Interspinous process decompression (IPD) system (X-STOP) for the treatment of lumbar spinal stenosis. Surg Technol Int. 2006;15:265-75.

30.Sénégas J, Vital JM, Pointillart V, Mangione P. Long-term actuarial survivorship analysis of an interspinous stabilization system. Eur Spine J. 2007;16(8):1279-87.

31.Khoueir P, Kim KA, Wang MY. Classification of posterior dynamic stabilization devices. Neurosurg Focus. 2007;22(1):E3.

32.Phillips FM, Voronov LI, Gaitanis IN, Carandang G, Havey RM, Patwardhan AG. Biomechanics of posterior dynamic stabilizing device (DIAM) after facetectomy and discectomy. Spine J. 2006; 6(6):714-22.

33.Serhan HA, Varnavas G, Dooris AP, Patwadhan A, Tzermiadianos M. Biomechanics of the posterior lumbar articulating elements. Neurosurg Focus. 2007; 22(1):E1.

34.McAfee P, Khoo LT, Pimenta L, Capuccino A, Sengoz A, Coric D, et al. Treatment of lumbar spinal stenosis with a total posterior arthroplasty prosthesis: implant description, surgical technique, and a prospective report on 29 patients. Neurosurg Focus. 2007;22(1):E13.

35.Kroeber M, Unglaub F, Guehring T, Nerlich A, Hadi T, Lotz J, Carstens C. Effects of controlled dynamic disc distraction on degenerated intervertebral discs: an in vivo study on the rabbit lumbar spine model. Spine. 2005;30(2):181-7.
36. Guehring T, Omlor GW, Lorenz H, Engelleiter K, Richter W, Carstens $\mathrm{C}$, et al. Disc distraction shows evidence of regenerative potential in degenerated intervertebral discs as evaluated by protein expression, magnetic resonance imaging, and messenger ribonucleic acid expression analysis. Spine. 2006; 31(15):1658-65.

37.Lafage V, Gangnet N, Sénégas J, Lavaste F, Skalli W. New interspinous implant evaluation using an in vitro biomechanical study combined with a finite-element analysis. Spine. 2007;32(16):1706-13.

38. Swanson KE, Lindsey DP, Hsu KY, Zucherman JF, Yerby SA. The effects of an interspinous implant on intervertebral disc pressures. Spine. 2003; 28(1):26-32.

39. Wiseman CM, Lindsey DP, Fredrick AD, Yerby SA. The effect of an interspinous process implant on facet loading during extension. Spine. 2005;30(8):903-7.

40.Palmer S, Mahar A, Oka R. Biomechanical and radiographic analysis of a novel, minimally invasive, extension-limiting device for the lumbar spine. Neurosurg Focus. 2007;22(1):E4.

41.Kirkaldy-Willis WH, Farfan HF. Instability of the lumbar spine. Clin Orthop Relat Res. 1982;(165):110-23.

\section{Correspondence}

Larry T. Khoo

Chief of Neurosurgery, UCLA Santa

Monica Hospital

Assistant Professor of Neurological \&

Orthopedic Surgery

1245 16th Street, Suite 200

Santa Monica, CA 90404

310-319-3295

E-mail: Ikhoo@mednet.ucla.edu 